Click

Here

Full

Article

\title{
Aging of marine organic matter during cross-shelf lateral transport in the Benguela upwelling system revealed by compound-specific radiocarbon dating
}

\author{
Gesine Mollenhauer \\ Woods Hole Oceanographic Institution, Woods Hole, Massachusetts, USA
}

Royal Netherlands Institute for Sea Research, Texel, Netherlands

Fachbereich Geowissenschaften, Universität Bremen, Bremen, Germany

Now at Alfred Wegener Institute for Polar and Marine Research, Am Handelshafen 12, D-27570 Bremerhaven, Germany (gesine.mollenhauer@awi.de)

\section{Maik Inthorn}

Fachbereich Geowissenschaften, Universität Bremen, Bremen, Germany

Now at SINTEF Petroleum Research, NO-7465 Trondheim, Norway

Thomas Vogt and Matthias Zabel

Department of Geosciences, University of Bremen, Klagenfurter Str., D-28359 Bremen, Germany

\section{Jaap S. Sinninghe Damsté}

Royal Netherlands Institute for Sea Research (NIOZ), Landsdiep 4, 1797 SZ 't Horntje (Texel), Netherlands

\section{Timothy I. Eglinton}

Marine Chemistry and Geochemistry, Woods Hole Oceanographic Institution, Mail Stop 4, 360 Woods Hole Road, Woods Hole, Massachusetts 02543-1543, USA

[1] Organic matter accumulation and burial on the Namibian shelf and upper slope are spatially heterogeneous and strongly controlled by lateral transport in subsurface nepheloid layers. Much of the material deposited in depo-centers on the slope ultimately derives from the shelf. Supply of organic matter from the shelf involves selective transport of organic matter. We studied these selective transport processes by analyzing the radiocarbon content of co-occurring sediment fractions. Here we present radiocarbon data for total organic carbon as well as three tracers of surface ocean productivity (phytoplankton-derived alkenones, membrane lipids of pelagic crenarchaeota (crenarchaeol), and calcareous microfossils of planktic foraminifera) in core-top and near-surface sediment samples. The samples were collected on the Namibian margin along a shelf-slope transect ( 85 to $1040 \mathrm{~m}$ ) at $24^{\circ} \mathrm{S}$ and from the upper slope depo-center at $25.5^{\circ} \mathrm{S}$. In core-top sediments, alkenone ages gradually increased from modern to 3490 radiocarbon years with distance from shore and with water depth. Crenarchaeol, while younger than alkenones, also increased in age with distance offshore. It was concluded that the observed ages were a consequence of cross-shelf transport and associated aging of organic matter. Radiocarbon ages of preserved lipid 
biomarkers in sediments thus at least partially depend on the relative amount of laterally supplied, pre-aged material present in a sample, highlighting the importance of nepheloid transport for the sedimentation of organic matter over the Namibian margin.

Components: 9071 words, 6 figures, 2 tables.

Keywords: compound-specific radiocarbon dating; sediment transport.

Index Terms: 3022 Marine Geology and Geophysics: Marine sediments: processes and transport; 3002 Marine Geology and Geophysics: Continental shelf and slope processes (4219); 1055 Geochemistry: Organic and biogenic geochemistry.

Received 7 February 2007; Revised 7 May 2007; Accepted 3 July 2007; Published 18 September 2007.

Mollenhauer, G., M. Inthorn, T. Vogt, M. Zabel, J. S. Sinninghe Damsté, and T. I. Eglinton (2007), Aging of marine organic matter during cross-shelf lateral transport in the Benguela upwelling system revealed by compound-specific radiocarbon dating, Geochem. Geophys. Geosyst., 8, Q09004, doi:10.1029/2007GC001603.

\section{Introduction}

[2] Continental margins play an important role in the global carbon cycle as areas of high primary productivity [Carr, 2001], sites of organic matter burial [Berner, 1982; Reimers et al., 1992; Wollast, 1998], and locations where terrigenous material enters the oceans. At present, shelf areas act as sediment traps and are sites of extensive reworking and associated organic carbon remineralization [Aller, 1998, 2004].

[3] On several continental margins, depo-centers located on the upper slopes have been observed, and lateral transport has been proposed as a mechanism to explain the spatial off-set between areas of highest production over the shelf and the depositional centers at greater water depths [Biscaye and Anderson, 1994; Keil et al., 1998]. For example, isotopic signatures of suspended particulate organic carbon (OC) on shelf-slope transects suggest offshore transport [Bauer et al., 2001]. Similarly, organic material in depo-centers of the upper slopes has been observed to contain significant portions of pre-aged OC [Hall and McCave, 1998]. An excellent example for the important role of bottom currents and resuspension of finegrained sediment for the preservation of organic matter was given by Arthur et al. [1998] in a study of the highly productive Peru margin.

[4] It has been shown that during offshore transport, labile organic matter is preferentially degraded. Refractory terrestrial organic compounds are better preserved and consequently become enriched in the sediments [Dickens et al., 2004]. The duration of such transport processes has not been studied in detail. Existing estimates are based on available data on particle transport and reach values of up to 1800 years for sites on the deeper continental slope on the northeast Pacific margin [Keil et al., 2004]. Evidence for efficient oxidation of both terrigenous and marine $\mathrm{OC}$ in studies of organic matter degradation on shelf muds is attended by isotopic changes, including depletion of ${ }^{14} \mathrm{C}$ in these sediments [Aller and Blair, 2004]. A recent radiocarbon study of suspended particulate organic matter from the nepheloid layer overlying the continental slope off Namibia has provided evidence that lateral transport in nepheloid layers leads to the burial of pre-aged organic matter (up to 3000 years old) in the slope sediments [Inthorn et al., 2006a]. However, bulk parameters of organic matter do not allow for separation of the effect of admixture of terrigenous organic material on processes that contribute to the apparent aging of organic matter during transport. Admixture of terrigenous organic material can be excluded when studying organic compounds derived from marine organisms on a molecular level.

[5] Alkenones are long-chain ketones produced by marine phytoplankton, mainly by the coccolithophorid species Emiliania huxleyi and Gephyrocapsa oceanica, and are thus suitable lipid biomarkers representing marine organisms. These compounds are often used for reconstruction of past sea-surface temperatures via the well-established $\mathrm{U}_{37}^{\mathrm{K}^{\prime}}$-index [Prahl et al., 1988; Müller et al., 1998]. Due to the habitat of the phytoplankton precursor species these lipids can be assumed to reflect conditions in near-surface waters, and their radiocarbon content has been shown to be equivalent to that of dissolved inorganic carbon (DIC) of the water they lived in [Mollenhauer et al., 2005]. A second lipid biomarker representative of marine planktic organ- 
isms is crenarchaeol. This glycerol dibiphytanyl glycerol tetraether (GDGT) compound derives from the membranes of mesophylic archaea of the kingdom crenarchaeota. Marine crenarchaeota are the most abundant single group of prokaryotes in the oceans [Karner et al., 2001]. Radiocarbon analysis of GDGT membrane lipids has shown that these organisms incorporate carbon with isotopic compositions equal to that of DIC in the surrounding water [Ingalls et al., 2006]. In spite of the occurrence of crenarchaeota throughout the water columns, GDGTs with variable numbers of cyclopentane rings have been shown to record SST via the $\mathrm{TEX}_{86}$ index [Schouten et al., 2002]. Furthermore, GDGTs preserved in the sediments likely derive predominantly from near-surface waters [Wuchter et al., 2005].

[6] Radiocarbon measurements of alkenones in sediments from the continental shelf and slope have been used to document redistribution of marine organic matter in the Benguela upwelling area [Mollenhauer et al., 2003]. Specifically, alkenones in core-top sediments from the inner shelf were found to be modern, whereas they were $\sim 2500{ }^{14} \mathrm{C}$ years old in a core top from the upper slope [Mollenhauer et al., 2003]. The age difference was interpreted as a consequence of gradual cross-shelf transport in repeated cycles of resuspension and resedimentation. Another explanation is the admixture of older sediments eroded near the core sites. It is also not known thus far whether the apparent aging during transport from the inner shelf to the upper slope is a gradual and continual process, whether most aging occurs on the shelf, or whether all shelf material is modern and the older slope ages result from the admixture of fossil material (e.g., material eroded at the shelf break).

[7] Here, we report measurements from a set of five cores taken along a transect across the Namibian continental shelf and upper slope. We present core-top and near-surface radiocarbon ages of alkenones, crenarchaeol, total organic carbon (TOC) and planktic foraminifera. We observe gradually increasing ages of all organic sediment constituents with distance from the shore and water depth and discuss these results in the context of cross-shelf lateral transport of organic matter.

\section{Study Area}

[8] The Benguela Upwelling System (BUS) is one of four major coastal upwelling systems in the world [Carr, 2001]. It has an estimated primary production of $0.37 \mathrm{Gt} \mathrm{C/yr} \mathrm{[Carr,} \mathrm{2001],} \mathrm{an} \mathrm{intense}$ and extensive oxygen minimum zone, and extraordinarily high organic carbon (OC) concentrations in underlying surface sediments (up to $\sim 20 \%$ dry weight; Figure 1) [Mollenhauer et al., 2002]. Much of the productivity occurs in waters overlying the continental shelf, and highest OC contents are observed in shelf sediments [Bremner, 1983; Mollenhauer et al., 2002; Inthorn et al., 2006a]. However, a second maximum in OC content in surface sediments occurs on the upper slope.

[9] Organic carbon in marine sediments can be assumed to be predominantly derived from marine sources. The spatial disposition of organic matter in the sediments of the BUS therefore suggests redistribution of fine-grained material by bottom currents. Organic-rich sediments are primarily deposited between $19^{\circ} \mathrm{S}$ and $27^{\circ} \mathrm{S}$. Notably, the rivers draining SW Africa reach the ocean at latitudes north of $19^{\circ} \mathrm{S}$ and south of $\sim 29^{\circ} \mathrm{S}$. Therefore a significant contribution of terrigenous organic matter to the organic-rich sediments supplied by rivers can be excluded. Significant contribution of terrigenous organic matter supplied by dust to the total OC of sediments in the study area can likewise be excluded on the basis of published OC contents of dust that are significantly lower than OC contents of sediments in the study area [Eglinton et al., 2002].

[10] The continental shelf off Southwestern Africa is relatively wide and deep with an outer shelf break at around $400 \mathrm{~m}$ water depth, as far as $\sim 150 \mathrm{~km}$ from the shoreline (Figure 1). A second, inner shelf break in 100-200 $\mathrm{m}$ water depth is observed over large parts of the upwelling area. Studies of shelf sediments have focused on biogenic sediment components, highlighting the dominant control of productivity on sediment composition [Bremner, 1983], and on clay mineralogy comparing the two major rivers discharging at the northern and southern boundaries of the upwelling system [Bremner and Willis, 1993].

[11] A mud belt of diatomaceous ooze particularly rich in OC, which accumulates on the inner shelf [Bremner, 1983], has been the focus of several recent studies [Struck et al., 2002; Emeis et al., 2004; Brüchert et al., 2006]. In contrast, much less is known about the sedimentation on the outer shelf, but the presence of a poleward undercurrent over this portion of the shelf suggests that little or no sedimentation occurs in these areas. Indeed, patterns of OC contents in surface sediments imply current-induced winnowing on the outer shelf [Mollenhauer et al., 2002]. A depo-center of 


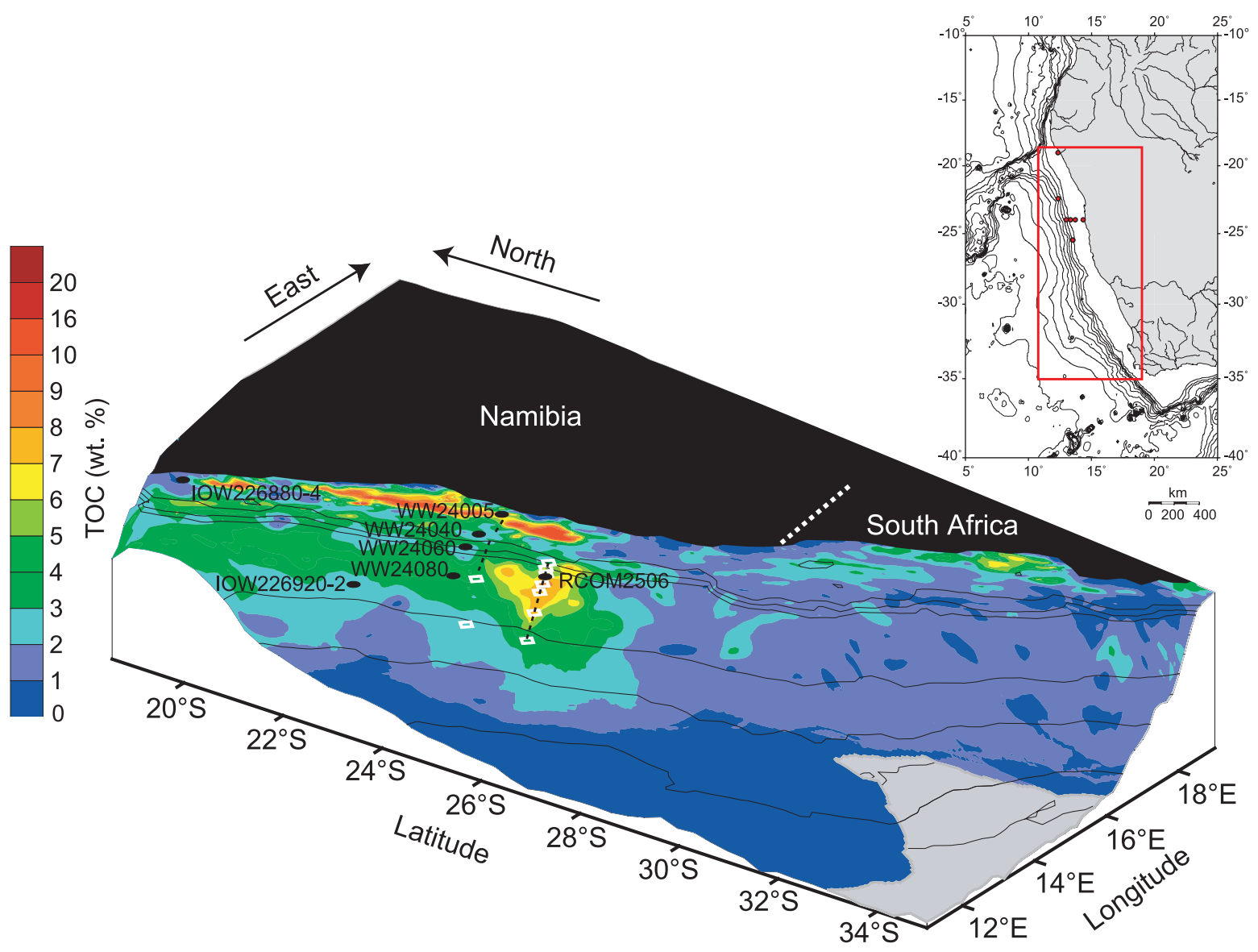

Figure 1. Map of the TOC content in surface sediments in the study area and sample site locations on the Namibian continental margin. The TOC map is adapted from Inthorn et al. [2006a]. Black dots indicate sample sites of multicorer cores from this study (WW24005, WW24040, WW24060, WW24080, and RCOM2506) and multicorer sites from Mollenhauer et al. [2003] (IOW226920-2 and IOW226880-4). White diamonds are sites where suspended particulate organic matter was radiocarbon dated [Inthorn et al., 2006a]. Black dashed lines mark the Parasound sediment echosounder profiles presented in Figures 3 and 4. The map inset shows major rivers with perennial runoff in the larger study area.

organic rich sediment exists on the upper slope, and it has been postulated that it acts as the ultimate sink for much of the material produced in surface waters overlying the adjacent shelf areas, which arrives there via subsequent offshore and down-slope transport [Mollenhauer et al., 2002; Mollenhauer et al., 2003; Inthorn et al., 2006a]. This heterogeneous pattern of sediment deposition implies variable sedimentation rates and thicknesses of Holocene sediments across the shelf and slope [Mollenhauer et al., 2002].

[12] The mean cross-shelf circulation in the BUS consists of a two-cell structure [Lass and Mohrholz, 2005]. Surface waters are transported offshore. The intermediate layer moves as a compensating counter-current in onshore direction, while the water in the bottom layer moves offshore. The main components of the circulation parallel to the coast are the aforementioned poleward undercurrent and the equatorward surface current. Forcing mechanisms for bottom water flow include internal tides and waves as well as Ekman and inertial flows [Lass and Mohrholz, 2005; Monteiro et al., 2005]. Sites of low bottom shear stress exerted by bottom currents typically are sites of high OC contents in the sediments [Monteiro et al., 2005], leading, for example, to the development of the inner shelf mud belt as an area of OC deposition.

\section{Samples and Analytical Methods}

[13] We studied surficial sediments from 5 sites recovered by multicorer during a cruise on board R/V Alexander von Humboldt in January 2004 (Table 1 and Figure 1). Four of these cores were 
Table 1. Core Locations ${ }^{\mathrm{a}}$

\begin{tabular}{lccccc}
\hline \multicolumn{1}{c}{ Core } & Latitude, ${ }^{\circ} \mathrm{S}$ & Longitude, ${ }^{\circ} \mathrm{E}$ & Water Depth, $\mathrm{m}$ & Cruise & Core-Top TOC Content, wt. \% \\
\hline WW24005 & 24.000 & 14.349 & 85 & AHAB1 & 5.2 \\
WW24040 & 23.996 & 13.717 & 256 & AHAB1 & 4.6 \\
WW24060 & 23.998 & 13.344 & 309 & AHAB1 & 2.8 \\
WW24080 & 24.002 & 12.999 & 1040 & AHAB1 & 4.3 \\
RCOM2506 & 25.472 & 13.529 & 646 & AHAB1 & 8.0 \\
IOW226920-2 & 22.449 & 12.358 & 1683 & M48-2 & 3.5 \\
IOW226880-4 & 19.016 & 12.344 & 98 & M48-2 & 9.2 \\
\hline
\end{tabular}

\footnotetext{
${ }^{\mathrm{a}}$ Cores from R/V Meteor cruise M48-2 have been discussed extensively by Mollenhauer et al. [2003]. Results are compared with data from this study.
}

taken on a transect across the continental shelf and upper slope near $24^{\circ} \mathrm{S}$ in water depths between 85 and $1040 \mathrm{~m}$. Core WW24005 was taken within the inner shelf mud belt with high TOC contents, while the other three cores on the transect (WW24040, WW24060 and WW24080) were retrieved from the outer shelf and upper slope in areas leaner in TOC. The fifth core (RCOM2506) was taken in $646 \mathrm{~m}$ water depth within the upper slope depocenter at $25.5^{\circ} \mathrm{S}$.

[14] From each multicorer core, we studied the top $(0-1 \mathrm{~cm})$ and bottom (ranging from $8-10 \mathrm{~cm}$ to 14-16 cm; Table 2) slices. Samples were freeze dried and subsequently homogenized using a metal spatula. A sub-sample was used for radiocarbon dating of TOC, following standard procedures [McNichol et al., 1994]. For extraction and purification of lipid compounds for radiocarbon analysis, the remaining dried and homogenized sediment (20-125 g dry weight) was extracted in a Soxhlet apparatus with dichloromethane and methanol (97:3) for $48 \mathrm{~h}$. Total lipid extracts were dried and saponified. Alkenones were purified following the procedure described by Ohkouchi et al. [2005a]. This procedure involves liquid extraction of neutral lipids from the saponified total lipid extracts using hexane, $\mathrm{SiO}_{2}$ column chromatography into three successively more polar fractions, urea adduction of the second fractions eluted with dichloromethane:hexane (2:1), and column chromatography with $\mathrm{AgNO}_{3}$-coated $\mathrm{SiO}_{2}$. The mass of the purified alkenone sample was estimated via quantification of a small aliquot using GC-FID.

[15] The third, most polar fractions of the saponified total lipid extracts eluted from the $\mathrm{SiO}_{2}$ columns with methanol were further fractionated and archaeal lipids were collected by liquid chromatography using methods described by Hopmans et al. [2000] and Smittenberg et al. [2002]. Fractions containing crenarchaeol were further purified by column chromatography $\left(\mathrm{Al}_{2} \mathrm{O}_{3}\right)$. The amount of crenarchaeol in the purified samples was determined by HPLC-MS analysis of a small aliquot, and by weighing of the total sample.

[16] Sub-samples of the solvent extracted sediment residues were wet-sieved over a $65 \mu \mathrm{m}$ and a $150 \mu \mathrm{m}$ sieve. Planktic foraminifera shells (G. bulloides and N. pachyderma d.) and shell fragments were hand-picked from the fraction $>150 \mu \mathrm{m}$ and submitted for radiocarbon dating. Carbonate microfossil radiocarbon ages are unlikely to be affected by prior treatment of the sediment with organic solvents [Ohkouchi et al., 2005b]. Carbonate samples were converted to $\mathrm{CO}_{2}$ by standard methodology [McNichol et al., 1994].

[17] The purified samples of alkenones and crenarchaeol were combusted $\left(850^{\circ} \mathrm{C}, 8 \mathrm{hr}\right)$ in precombusted and evacuated quartz ampoules in the presence of precombusted $\mathrm{CuO} . \mathrm{CO}_{2}$ was reduced to graphite for radiocarbon dating, using procedures for regular sized $(>300 \mu \mathrm{g} \mathrm{C})$ and small samples, according to sample yield [Pearson et al., 1998]. The latter method involves a correction of measured results using size-matched standards analyzed during the same period.

[18] Preparation of samples consisting of organic matter involves the risk of blank carbon being added during the combustion process. In contrast to the blanks associated with graphitization, target preparation and machine-induced processes, the combustion blank cannot be corrected for by analysis of size-matched standards. When analyzing samples containing less than the standard amount carbon required for AMS analysis $(\sim 1 \mathrm{mg})$, the relative contribution of blank carbon added during the conversion to $\mathrm{CO}_{2}$ (i.e., combustion for samples of organic material) increases. The size of this carbon blank was determined at NOSAMS to be $0.08 \pm 0.02 \mu \mathrm{mol}$, and its radiocarbon content was found to be $\mathrm{fMC}=0.25 \pm 0.013 \mathrm{C}$ [Pearson et al., 1998]. Consequently, these values were used for a 


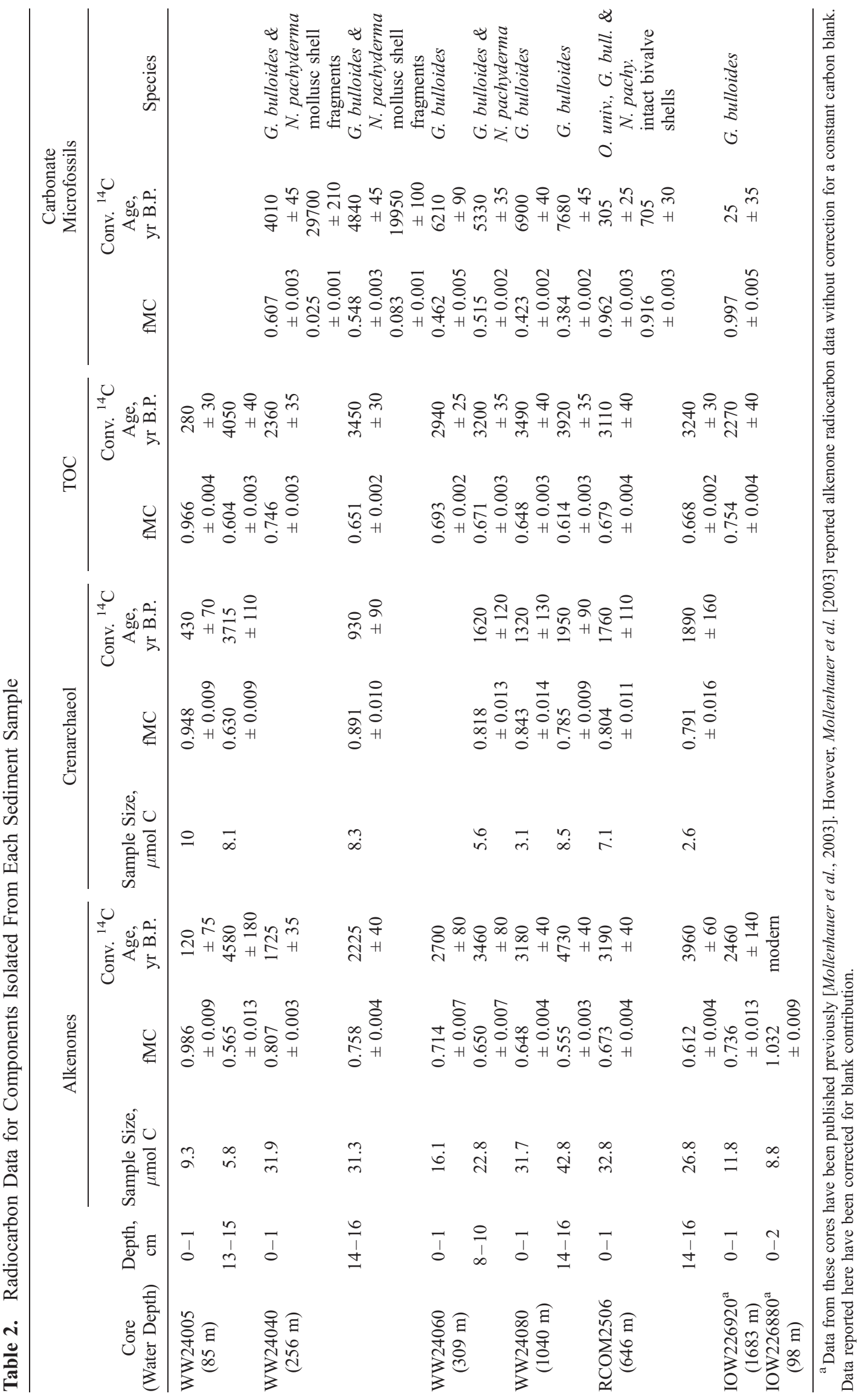


blank correction for our compound-specific radiocarbon ages assuming a constant blank contribution. Conventional radiocarbon ages were not converted to calendar ages because information on reservoir ages in the BUS is not available, and because of the possible influence of bomb radiocarbon in core-top sediments.

[19] All radiocarbon measurements were performed at the National Ocean Sciences Accelerator Mass Spectrometry (NOSAMS) facility at Woods Hole Oceanographic institution. Results are reported as fraction modern carbon (fMC) and conventional radiocarbon ages [Stuiver and Polach, 1977]. These notations involve a correction for isotope fractionation occurring during sample formation or processing; i.e., all data are normalized to a $\delta^{13} \mathrm{C}$ value of $-25 \%$. In this way, carbonate and organic matter samples can be compared.

\section{Results and Discussion}

\subsection{Radiocarbon Ages of Organic Compounds and TOC}

[20] Radiocarbon data are presented in Table 2. All dated sediment constituents were of Holocene age $\left({ }^{14} \mathrm{C}\right.$ ages $<9000$ yr B.P.). Gradually increasing radiocarbon ages with distance from the coast and with water depth are observed with all core-top alkenone, and TOC ages (Figure 2). Core-top alkenone ages ranged from $120 \pm 75$ to $3190 \pm 40{ }^{14} \mathrm{C} \mathrm{yr}$ B.P. TOC in core tops was between $280 \pm 30$ and $3490 \pm 40{ }^{14} \mathrm{C}$ yr B.P. old. Crenarchaeol in the core top of the inner shelf core was $430 \pm 70$ and $1320 \pm$ $130{ }^{14} \mathrm{C}$ yr B.P. at the deepest site of the transect. The off-transect site from the depo-center contained even older crenarchaeol in the core top (1760 \pm $110{ }^{14} \mathrm{C}$ yr B.P.). Core-bottom radiocarbon ages of organic sediment constituents were older than corresponding core-tops in all cases. Crenarchaeol shows a pattern of aging with distance from the shore in the core-bottom samples from sites WW24040, WW24060, and WW24080 with ages ranging from $930 \pm 90$ to $1950 \pm 90{ }^{14} \mathrm{C}$ yr B.P. The oldest dated crenarchaeol sample was from the core-bottom of the shallow site WW24005 with an age of $3715 \pm 110{ }^{14} \mathrm{C}$ yr B.P., which again is younger than co-occurring alkenones (4580 \pm $180{ }^{14} \mathrm{C}$ yr B.P.) and TOC $\left(4050 \pm 40{ }^{14} \mathrm{C}\right.$ yr B.P.). Sediments whose conventional radiocarbon ages are younger than the reservoir age, which may be up to $\sim 1000$ years in an upwelling area [Ingram and
Southon, 1996], can be regarded as modern or recent, as they probably contain some bomb-radiocarbon.

[21] Several possible scenarios can explain the increase of core-top ages across the transect from modern on the inner shelf to an age of several thousand years in the upper-slope depo-center. The apparent aging could be gradual, leading to a systematically increasing radiocarbon age with water depth. Alternatively, aging could occur only on the slope in water depths beyond the shelf break, whereby all shelf sediments would be modern. Last, it could be predominantly related to processes occurring on the shelf. Our data suggest that the latter scenario is an adequate description for the Namibian shelf radiocarbon ages of alkenones, TOC and partly of crenarchaeol, although fewer data are available for the latter compound (Figure 2a). The scenario is further supported by radiocarbon ages of suspended matter, which is up to $\sim 2800{ }^{14} \mathrm{C}$ yrs B.P. old, very similar to core-top radiocarbon ages of TOC in corresponding water depths (Figure 2b) [Inthorn et al., 2006a].

[22] The two main influences on core-top radiocarbon age are vertical displacement of sediment particles by bioturbation, which may be particlesize or -type selective [Bard, 2001], and lateral transport processes, e.g., by bottom currents, that may be similarly particle-selective and result in differential redistribution of sedimentary components. Admixture of pre-aged terrigenous organic matter can be excluded when discussing molecularlevel radiocarbon ages of compounds derived from marine organisms.

\subsection{Bioturbation}

[23] Vertical displacement by bioturbation has been extensively discussed in the literature [Guinasso and Schink, 1975; Bard et al., 1987; Thomson et al., 1995, 2000; Trauth et al., 1997; Anderson, 2001; Bard, 2001]. Its effect can be approximated by assuming that vertical mixing occurs within a distinct layer below the sediment-water interface; sediment below this mixed layer is considered to be undisturbed by further bioturbation. If bioturbation is assumed to create a homogenized mixed layer, we can estimate the potential effect of bioturbation on core-top radiocarbon ages and assess whether its effect can account for the "old core-top ages. To do this, either the sedimentation rate or the mixed layer depth has to be known.

[24] In a first exercise we use existing information on the depth of a homogenized mixed layer. 


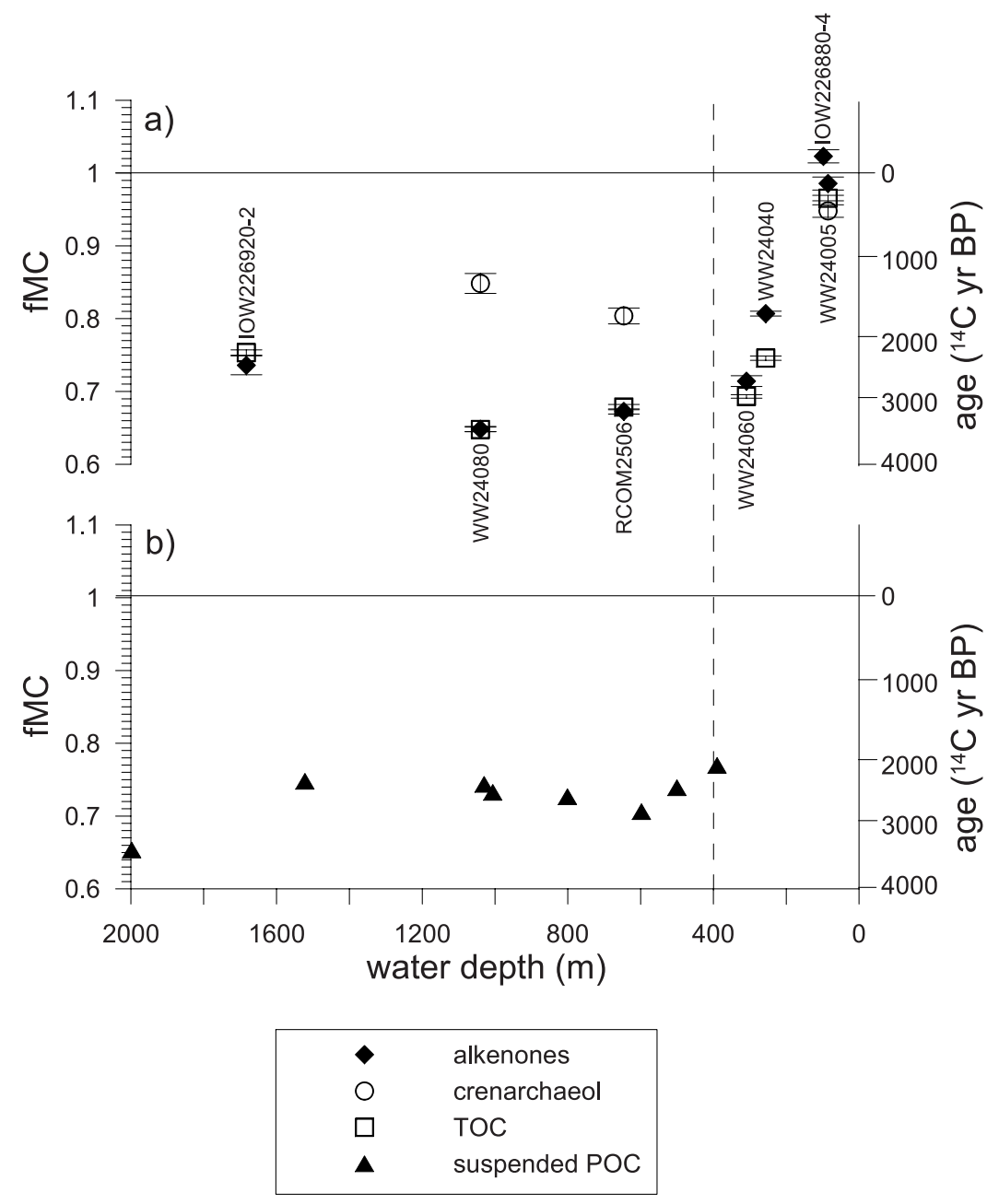

Figure 2. Radiocarbon data expressed as fMC (fraction modern carbon) plotted versus water depth. The dashed vertical line marks the approximate water depth of the outer shelf break off Namibia. (a) Radiocarbon data from coretop sediments investigated in this study and from Mollenhauer et al. [2003]. (b) Radiocarbon data from suspended particulate organic matter collected in the bottom nepheloid layer [Inthorn et al., 2006a].

${ }^{210} \mathrm{~Pb}_{\mathrm{xs}}$ measurements in several cores from the Namibian shelf and upper slope have revealed that the mixed layer depth in this area averages $10 \mathrm{~cm}$ (T. Ferdelman, unpublished data, 2005). On the basis of this, we can estimate the potential influence of bioturbation on the radiocarbon age of preserved organic compounds and TOC for our core sites for scenarios with different sedimentation rates. The estimates are based on the calculation of average $\mathrm{fMC}$ values within the hypothetical mixed layer, which are subsequently converted to conventional radiocarbon ages.

[25] The radiocarbon age of a homogenized layer of $10 \mathrm{~cm}$ thickness would be approximately 5970 ${ }^{14} \mathrm{C}$ years, if the sedimentation rate were $1 \mathrm{~cm} \mathrm{kyr}^{-1}$. At sedimentation rates of 3,5 , and $10 \mathrm{~cm} \mathrm{kyr}^{-1}$, the age of the $10 \mathrm{~cm}$-thick homogenized mixed layer would be 2650,1940 , and $1400{ }^{14} \mathrm{C}$ years, respectively. The measured core-top ages are up to $3500{ }^{14} \mathrm{C}$ years (e.g., TOC at WW24080). This value falls within the range of calculated values for sedimentation rates between 1 and $3 \mathrm{~cm} \mathrm{kyr}^{-1}$ and would thus imply that sedimentation rates were less than $3 \mathrm{~cm} \mathrm{kyr}^{-1}$ if the "old" core-top ages were the result of homogenization of the upper $10 \mathrm{~cm}$ of the sediment alone. Comparison with existing data on sedimentation rates allows assessing whether this is a realistic scenario. Sedimentation rates in the inner shelf mud belt off Namibia calculated using radiocarbon ages of planktic foraminifera have been reported to reach values in excess of $50-60 \mathrm{~cm}$ $\mathrm{kyr}^{-1}$ [Mollenhauer et al., 2002; Struck et al., 2002; K.-C. Emeis et al., Variability in the coastal upwelling system offshore Namibia, submitted to International Journal of Earth Sciences, 2007]. 
Sedimentation rates of 5-17 $\mathrm{cm} \mathrm{kyr}^{-1}$ were found at most of the slope sites off Namibia [Mollenhauer et al., 2002]. Low sedimentation rates of less than $3 \mathrm{~cm} \mathrm{kyr}^{-1}$ are thus regarded unlikely to occur on the highly productive Namibian margin. Therefore bioturbation down to $10 \mathrm{~cm}$ as the sole cause for elevated core-top radiocarbon ages is regarded an unlikely scenario.

[26] In a second exercise, mixed layer depths can be estimated on the basis of the measured core-top radiocarbon age and assuming values for sedimentation rates. If the sedimentation rate was 2,5 , and $10 \mathrm{~cm} \mathrm{kyr}^{-1}$, a core-top age of $3500{ }^{14} \mathrm{C}$ would require homogenization down to about 10,25 , and $50 \mathrm{~cm}$, respectively. The fact that all measured organic constituents in core bottoms at sediment depths between $8-10$ and $14-16 \mathrm{~cm}$ were older than in the corresponding core tops (Table 2) indicates that bioturbation did not result in complete homogenization down to these depths. Therefore we conclude that vertical sediment movement by bioturbation alone cannot explain the observed core-top radiocarbon ages.

\subsection{Advection of Pre-aged Organic Matter}

[27] Lateral supply of pre-aged organic matter transported by bottom currents is another possible explanation for the observed ages. Each sample likely represents mixtures of material that is fresh and pre-aged advected material. The fresh material is vertically supplied to the seafloor from the overlying water column. In contrast, the advected organic matter could either derive from fossil sedimentary deposits that have been eroded elsewhere, or organic matter that has aged during transport (implying that the particles remain susceptible to resuspension from the sediment bed for millennia), or old organic matter could be supplied from both types of sources. Aged organic matter may be protected from degradation by adsorption onto mineral surfaces [Mayer et al., 2004]. Together with the effects of bioturbation, the relative proportions of the pre-aged advected and the vertically supplied contributions will determine the measured radiocarbon age.

[28] Clear evidence that lateral transport strongly influences the distribution and age of organic matter in surface sediments comes from ${ }^{14} \mathrm{C}$ ages of suspended material collected from bottom nepheloid layers (within $\sim 0.3 \mathrm{~m}$ of the seafloor) near the core sites investigated in a prior study [Inthorn et al., 2006a]. This suspended particulate organic matter is very similar in age to the organic matter in underlying core-top sediments (Figure 2b), implying that transport in nepheloid layers exerts a strong influence on sedimentation on the Namibian shelf and slope.

[29] Nepheloid layers in the water column and near the seafloor were mapped on three cross-shelf transects by [Inthorn et al., 2006b]. Although these measurements represent only a snapshot in time, the water column particle distributions observed in that study suggests that all of our core sites with older than modern core-top radiocarbon ages underlie areas with pronounced bottom nepheloid layers. Highest intensity of the bottom nepheloid layer near the outer shelf break and an intermediate nepheloid layer extending from the shelf break across the upper slope indicate particle resuspension on the outer shelf and transport of the resuspended particles toward the slope depo-center. No data were obtained near the inner shelf mud belt.

[30] Monteiro et al. [2005] discussed the relationship between current velocities near the seafloor and organic carbon contents in the underlying sediments and found the two parameters to be inversely correlated. The authors concluded that resuspension of organic-rich particles by internal tides and advective transport of the particles by elevated Ekman and inertially forced bottom flows are the main controlling factors for the distribution of organic carbon in Namibian shelf and slope sediments. Low bottom shear stress was found near the inner-shelf mud belt, which is where we see near-modern radiocarbon ages in core tops. Furthermore, strongest current energy related to tides was found near the shelf breaks [Monteiro et al., 2005]. Our data serve to underline the importance of current-induced transport near the seafloor for the sedimentary record, and also imply that pre-aged organic material is redistributed by this process.

[31] It has been proposed that highest tidal shear stresses prevail near the shelf breaks on the Namibian margin [Monteiro et al., 2005]. At these sites, the zonal component of currents may reach values of up to $20 \mathrm{~cm} \mathrm{~s}^{-1}$ [Lass and Mohrholz, 2005; Monteiro et al., 2005]. A Parasound echosounder profile recorded near $24.25^{\circ} \mathrm{S}$ reveals that the shelf breaks may even be areas where older sediments are eroded due to these currents (Figure 3). In particular, truncated reflectors are observed below the outer shelf break between ca. 400 and $850 \mathrm{~m}$ water depth, suggesting that in this depth range, current energy results in a net erosional situation. 


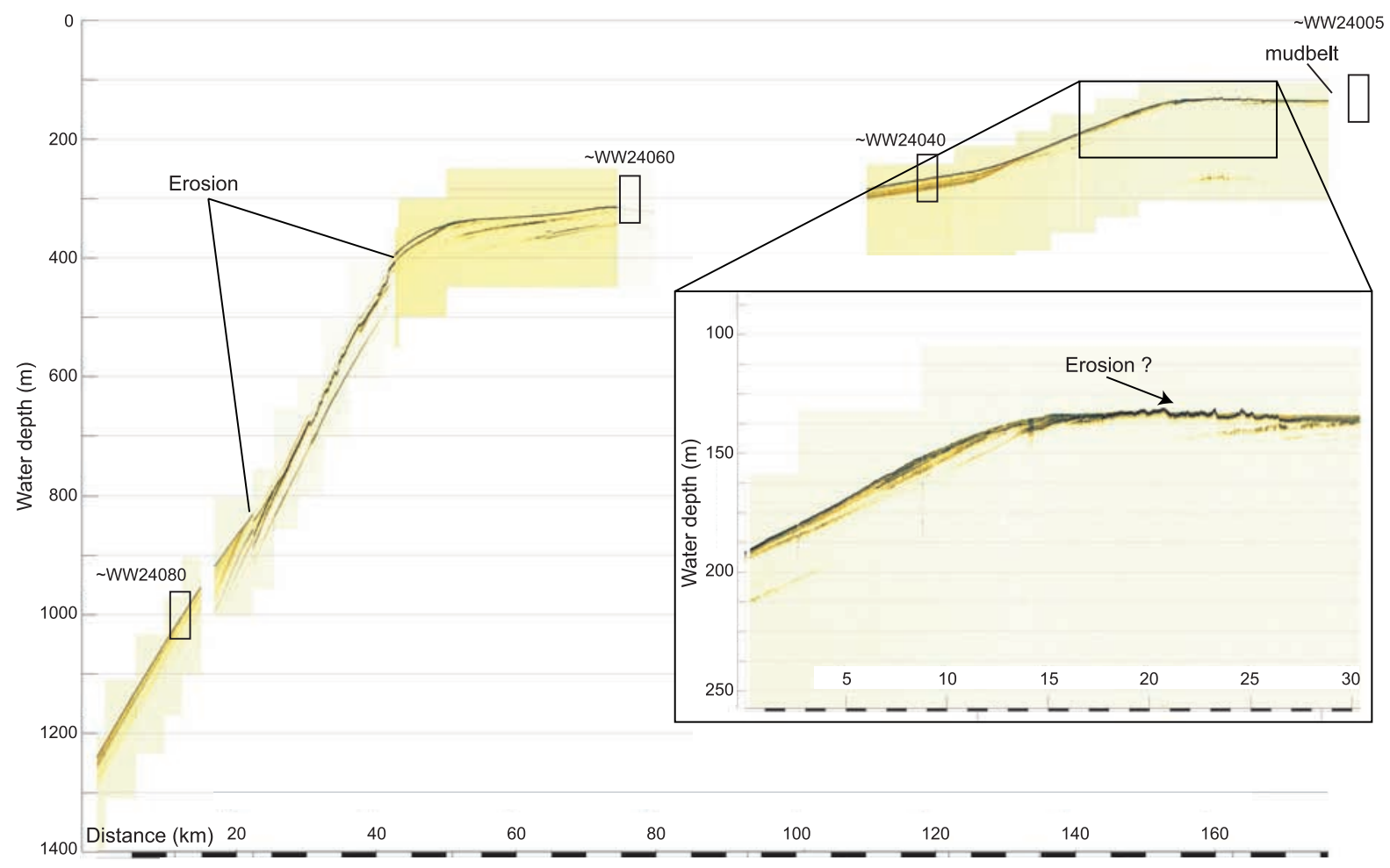

Figure 3. Parasound sediment echosounder profile recorded during R/V Meteor cruise $\mathrm{M} 57 / 2$ between approximately $24.37^{\circ} \mathrm{S}, 13.22^{\circ} \mathrm{E}$ and $24.25^{\circ} \mathrm{S}, 13.61^{\circ} \mathrm{E}$ (lower portion) and between $24.20^{\circ} \mathrm{S}, 13.90^{\circ} \mathrm{E}$ and $24.13^{\circ} \mathrm{S}, 14.17^{\circ} \mathrm{E}$ (upper portion). Outlined boxes indicate approximate locations of cores studied here (see text). Truncated reflectors near the outer shelf break are indicators for erosion. Thinned sediment cover and pinnacle-like structures near the inner shelf break may be related to erosive processes as well. No data were recorded at the innershelf mud belt.

The Parasound profile was recorded slightly to the south of the core sites WW24005 to WW24080, so the areas of erosion may not be located in exactly the same water depths at the latitude of our core transect. Evidence for erosion is less clear at the inner shelf break. However, in water depths near $130 \mathrm{~m}$, which is located above the actual morphological shelf break, reflectors are thinning out (Figure 3). Interestingly, this is also an area where currents with offshore components of up to $20 \mathrm{~cm} \mathrm{~s}^{-1}$ have been reported [Lass and Mohrholz, 2005].

[32] A second Parasound profile recorded at $25.5^{\circ} \mathrm{S}$ almost exactly across the site where core RCOM2506 was retrieved is presented in Figure 4. No evidence for erosion below the shelf break can be found on this echogram. Instead, undisturbed and thickening-downslope sediment layers are observed between 400 and $700 \mathrm{~m}$ water depth.
[33] Taken together, the observations suggest that the old core-top radiocarbon ages are at least in part caused by erosion and remobilization of older sediments exposed at the shelf break. The contribution of eroded material, particularly of the coarser size fraction, is likely larger at the sites on the northern transect than at the depo-center site.

\subsection{Offshore Gradients in Organic Matter Quality}

[34] Comparison of two different marine biomarkers, the alkenones and the archaeal lipid crenarchaeol (Table 2), reveals that different biomarkers from the same sediment layer may differ significantly in radiocarbon age as observed previously [Eglinton et al., 1997; Pearson et al., 2001; Smittenberg et al., 2004]. The radiocarbon age difference between co-occurring alkenones and crenarchaeol implies that either the pre-aged mate- 


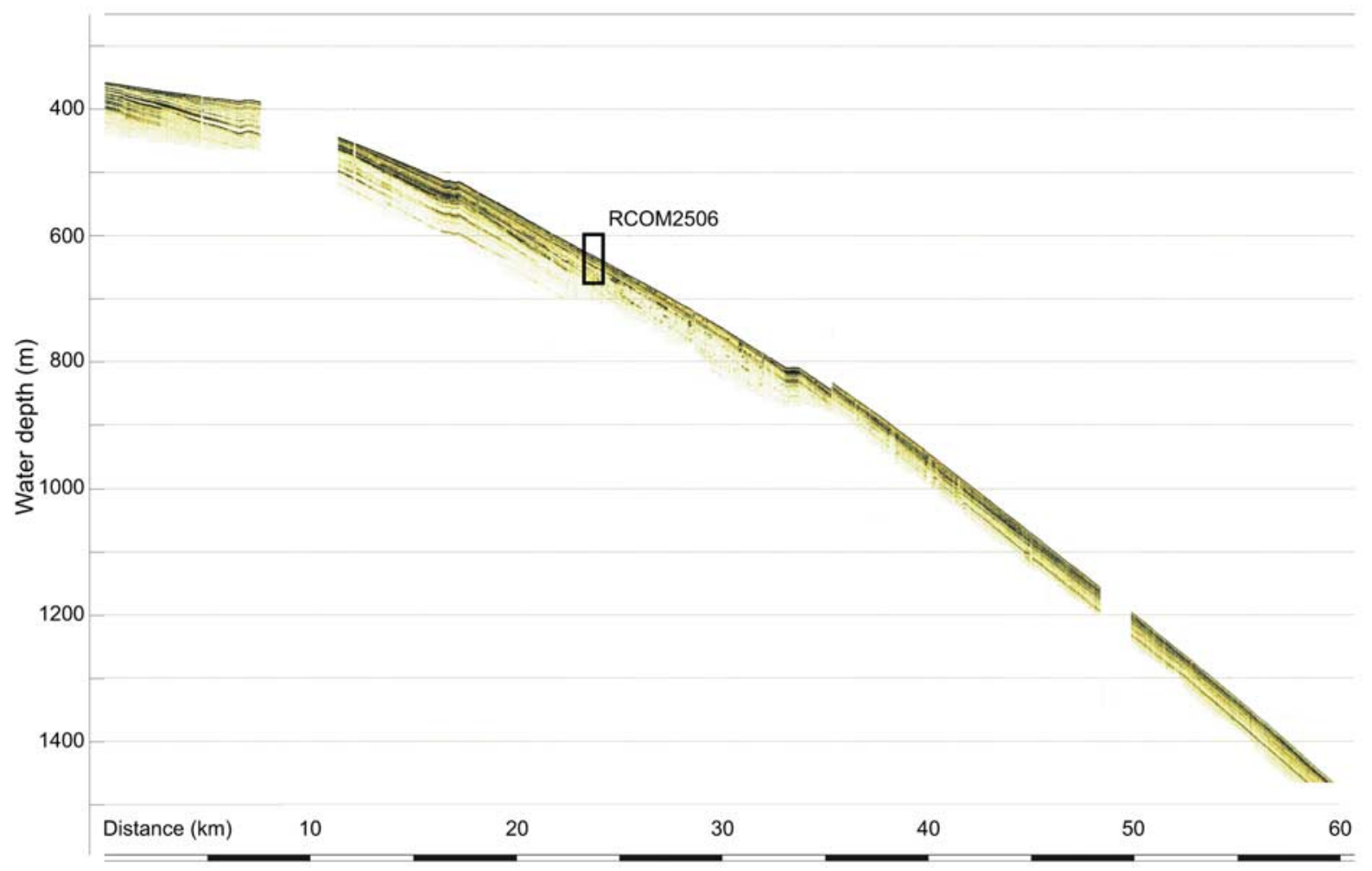

Figure 4. Parasound sediment echosounder profile recorded during R/V Meteor cruise $\mathrm{M} 57 / 2$ between approximately $25.43^{\circ} \mathrm{S}, 13.69^{\circ} \mathrm{E}$ and $25.51^{\circ} \mathrm{S}, 13.18^{\circ} \mathrm{E}$. Apparent steps in the seafloor reflector are artifacts and originate from the ship's drift during station work. Core RCOM2506 was retrieved near the shallower end of a zone with thickening layers and weak reflectors, likely corresponding to the depo-center on the upper slope.

rial advected to the core sites contains less crenarchaeol than alkenones (e.g., due to higher alkenone production on the inner shelf), or that the crenarchaeol initially present in the advected material is more rapidly degraded during lateral transport and thus only a small fraction of pre-aged crenarchaeol is preserved, whereas alkenones are less efficiently degraded during transport. Our observations on the Namibian shelf and slope thus support the notion that the aging of the organic matter is associated with loss of labile organic matter with younger radiocarbon ages. The differences in preservation of the individual compounds may result either from different resistivity of the compounds to degradation in oxygenated water or from more efficient protection of one compound than the other, e.g., by adsorption onto mineral surfaces.

[35] This observation concerns the relative preservation potentials of crenarchaeol and alkenones. Prior studies on relative preservation efficiencies of alkenones and crenarchaeol yielded inconclusive results [Sinninghe Damsté et al., 2002]. The fact that crenarchaeol is younger than co-occurring alkenones in all samples by 690 to $2780{ }^{14} \mathrm{C}$ years, and that this age difference increases with increasing radiocarbon age of the alkenones (except for the core bottom of the inner shelf core) argues for more rapid degradation of crenarchaeol than alkenones, if we assume that in-situ production of crenarchaeol can be excluded. Evidence that crenarcheol isolated from laminated marine sediments reflects surface water radiocarbon content [Smittenberg et al., 2004] implies that this assumption is valid. The radiocarbon age difference between the two compounds remains constant, within error, in the two samples from the inner shelf core. This observation lends further support to a strong effect of preferential degradation on the radiocarbon age of preserved biomarkers, as discussed in more detail by Mollenhauer and Eglinton [2007] for sediments from the California Borderland Basins. Alternatively, the particles the compounds are associated with (e.g., adsorbed on mineral surfaces, entrained in organic aggregates) may not be equally susceptible to transport.

[36] Rock-Eval pyrolysis [Tissot and Welte, 1984] was performed by Inthorn et al. [2006a] on the 

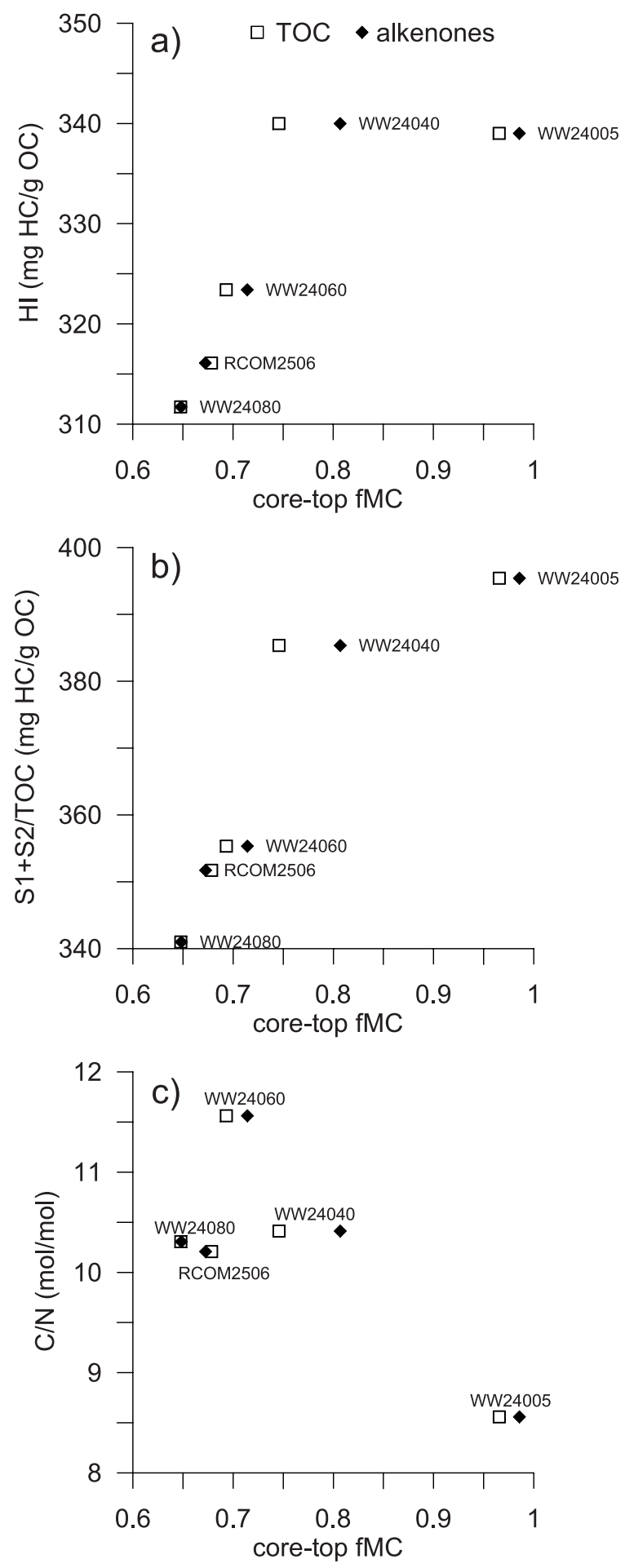

Figure 5. (a) Hydrogen Index (HI) from Rock-Eval pyrolysis plotted versus core-top fMC of TOC and alkenones from the same sediment samples. (b) Modified $\mathrm{HI}$ (see text) plotted versus fMC of TOC and alkenones. (c) $\mathrm{C} / \mathrm{N}$ values [Inthorn et al., 2006a] plotted versus $\mathrm{fMC}$ of TOC and alkenones. samples discussed here and provides information on the composition and degree of transformation of organic matter [Liebezeit and Wiesner, 1990; Calvert et al., 1992; Arthur et al., 1994]. Yields of the pyrolysis are expressed with the hydrogen index (HI) calculated from the amount of pyrolysate released between 300 and $550^{\circ} \mathrm{C}\left(\mathrm{S}_{2}\right.$ peak) normalized to the TOC content [Espitalié et al., 1977]. HI values of our surface sediments range between 310 and 350 . HI is correlated with coretop $\mathrm{AMC}$ of TOC and alkenones and decreases in an offshore direction (Figure 5a). If the shallowest core is excluded, this correlation between $\mathrm{HI}$ and alkenone core-top fMC is very tight and virtually linear $\left(\mathrm{r}^{2}>0.99\right)$. The total amount of pyrolysate generated at temperatures below $550^{\circ} \mathrm{C}\left(\mathrm{S}_{1}\right.$ and $\left.\mathrm{S}_{2}\right)$ normalized to TOC content ("modified HI") shows significant correlations with core-top fMC as well $\left(\mathrm{r}^{2}=0.89\right.$ for alkenones and $\mathrm{r}^{2}=0.77$ for TOC; Figure 5b). These correlations imply that, not surprisingly, the organic matter in the core tops looses labile material as its age increases. This could reflect a selective loss of labile constituents with "young" radiocarbon signatures. The offshore decrease in HI values of the core-top sediments is consistent with a gradual offshore transport of organic matter as previously proposed [Mollenhauer et al., 2003; Inthorn et al., 2006a]. Labile organic constituents are lost (remineralized) during this transport. Loss of labile organic matter is also reflected in the increase of $\mathrm{C} / \mathrm{N}$ ratios with decreasing $\mathrm{fMC}$ (Figure 5c).

[37] A similar observation was made on the Peruvian margin, where comparable HI values were observed [Arthur et al., 1998]. The authors of that study identified active resuspension of surficial organic matter and transport of finegrained sediment to and from more oxygenated zones as the controlling factors. These processes were found to result in greater degradation than expected under oxygen-deficient conditions and successive loss of labile OM. Our data indicate that equivalent processes occur in the similarly productive Namibian margin setting. In contrast to the prior study from off Peru, however, we regard the influence of internal waves and tides to be stronger than that of the pole-ward undercurrent.

[38] It is likely that the advected material is heterogeneous, unevenly distributed over the shelf, and contains variable proportions of very refractory organic matter. Moreover, the latter may be less easily redistributed than the fresher material, which resides in the fluffy layer on the sediment surface. 


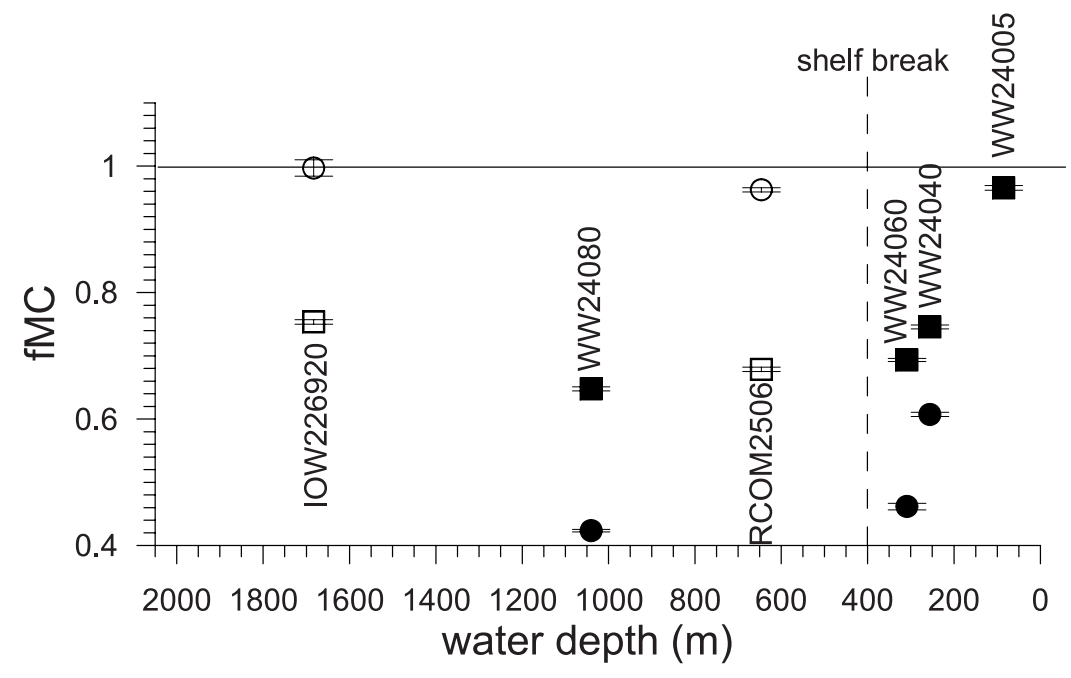

- $\bigcirc$ planktic foraminifera

$\square$ TOC

Figure 6. Core-top fMC of planktic foraminifera (circles) and TOC (squares). Filled symbols refer to transect sites WW24005, WW24040, WW24060, and WW24080. Open symbols are data from site RCOM2506 (646 m water depth) to the south of the transect, and site IOW226920 (1683 m water depth) north of the transect.

Support for this interpretation comes from larger age differences between TOC and alkenones at site WW24040 (256 m) than at the other sites on the transect. TOC is older than alkenones in both coretop and -bottom samples, whereas in other samples, TOC radiocarbon ages are identical to those of alkenones or somewhat younger. Considering the proximity of site WW24040 to the inner shelf break, we can speculate that the old TOC and younger alkenone radiocarbon ages reflect input of coarser grained, highly refractory material that is depauperate in lipids. Improved understanding of the depositional patterns awaits combined sedimentological and radiocarbon studies (using, e.g., grain-size distribution and hydrodynamic characteristics of particles).

[39] In an area with high bottom shear-stress such as the Namibian slope [Lass and Mohrholz, 2005; Monteiro et al., 2005], old core-top ages could also imply that presently no deposition occurs at these sites. However, all radiocarbon ages of TOC, alkenones, and crenarchaeol in all core tops and core bottoms are of Holocene age, and the corebottom sediments were older than in the corresponding core tops (Table 2). These results thus argue against erosion at the core sites and imply deposition during the late Holocene. The occurrence of present-day sediment deposition influenced by lateral particle advection is also suggested by the distribution of the natural isotope ${ }^{234} \mathrm{Th}$ in the bottom nepheloid layer and uppermost sediment horizons of the Namibian continental slope [Inthorn et al., 2006c].

\subsection{Radiocarbon Ages of Foraminifera and Bivalve Shells}

[40] A marked difference exists between the radiocarbon ages of foraminifera in surficial sediments from the shelf and slope at $24^{\circ} \mathrm{S}$ and those from the slope at sites to the north and south (Figure 6). While foraminifera from core-top sediments at site IOW226920 near $22.5^{\circ} \mathrm{S}$ [Mollenhauer et al., 2003] and from site $\mathrm{RCO} 2506$ at $25.5^{\circ} \mathrm{S}$ showed influence of bomb radiocarbon, foraminifera from core tops along the transect were surprisingly old. Moreover, at sites WW24040, WW24060, and WW24080, foraminiferal radiocarbon ages were older than all those obtained for organic matter from the same samples. Mollusc shell fragments (up to $\sim 0.5 \mathrm{~cm}$ diameter) recovered from site WW24040 had radiocarbon ages as high as $19,950 \pm 100{ }^{14} \mathrm{C} \mathrm{yr}$ $\left(14-16 \mathrm{~cm}\right.$ ) and $29,700 \pm 210{ }^{14} \mathrm{C}$ yr (core top). In contrast, intact bivalve shells at site RCOM2506 were dated at $705 \pm 30{ }^{14} \mathrm{C}$ yr, likely reflecting the reservoir age of bottom water for this location at $\sim 650 \mathrm{~m}$ water depth.

[41] These old foraminiferal radiocarbon ages at sites WW24040, WW24060, and WW24080 can only be explained by presence of fossil, reworked sediments. The individual sediment fractions with different radiocarbon ages must contain different 
proportions of fresh and pre-aged material, which suggests a composition of the advected material that is distinct from recent sediments. The reworked sediment could even be a coarse-grained foraminifera-rich relict deposit, considering the fact that foraminifera at our core sites are much older and thus may be much more strongly affected by admixture of fossil material than organic sediment constituents. This lends further support to the hypothesis that erosion of older sediments and advection of the eroded material to the core site influences core-top ages. In addition, the young core-top ages of foraminifera and bivalve shells in the depo-center near $25.5^{\circ} \mathrm{S}$ indicate little or no contribution, of eroded coarse-grained material. Lack of erosion at this latitude is corroborated by the Parasound profile (Figure 4).

[42] Stable oxygen isotope values obtained from G. bulloides from core-top sediments ranged from $0.58 \pm 0.04 \%$ VPDB (RCOM2560) to $1.03 \pm$ 0.02\% VPDB (WW24040), similar to Holocene values reported from slope cores [Mollenhauer et $a l ., 2003]$. Stable oxygen isotope values during the last glacial were found to be near 3\% VPDB [Mollenhauer et al., 2003]. We would thus expect values more enriched in ${ }^{18} \mathrm{O}$ if the old core-top ages of foraminifera were due to admixture of glacial-age foraminifera. There is therefore no clear indication for presence of substantial amounts of foraminifera from the last glacial. The foraminifera samples likely consist of a mixture of vertically supplied modern zooplankton shells and fossil material supplied to the sediments laterally, which is much older and can be assumed to be radiocarbon dead. In contrast, the glacial age mollusc shell fragments were strongly reworked, which may indicate an origin from very shallow water, possibly from a fossil beach deposit. Their radiocarbon age implies that this deposit was eroded during the post-glacial transgression.

\section{Conclusions}

[43] Despite a highly dynamic and heterogeneous sedimentary environment, deposition of organic material occurs at all study sites on the Namibian shelf and slope. The gradual offshore increase in core-top radiocarbon age of TOC, alkenones, and crenarchaeol reflects offshore transport and variable input of pre-aged material, likely derived at least in part from erosion of sediments exposed on or near the shelf breaks. Transport predominantly occurs in bottom nepheloid layers maintained and driven by tidal wave energy. Organic matter quality of core-top sediments, as indicated by Rock-Eval Hydrogen Indices, varies with the radiocarbon content of TOC and alkenones and decreases offshore as a result of preferential degradation of labile compounds. Together, the evidence from specific radiocarbon ages of different marine lipids and from Rock-Eval pyrolysis implies that the old core-top radiocarbon ages observed on the Namibian shelf and slope are largely a consequence of advection of pre-aged material, and its chemical alteration during transport. Bioturbation is an additional factor at the sites outside of the inner-shelf mud belt.

\section{Acknowledgments}

[44] We thank Ellen Hopmans and Daniel Montluçon for support with organic compound purification. Monika Segl performed stable oxygen isotope analyses. Helpful comments from Till Hanebuth contributed to the interpretation. Tim Ferdelman is thanked for providing unpublished data. Suggestions from two anonymous reviewers helped improve the manuscript. This work was funded by NSF grant OCE0327405 to T.I.E. and by a Spinoza grant to J.S.S.D. from NWO.

\section{References}

Aller, R. C. (1998), Mobile deltaic and continental shelf muds as suboxic, fluidized bed ractors, Mar. Chem., 61, $143-155$.

Aller, R. C. (2004), Conceptual models of early diagenetic processes: The muddy seafloor as an unsteady, batch reactor, J. Mar. Res., 62, 815-835.

Aller, R. C., and N. Blair (2004), Early diagenetic remineralization of sedimentary organic $\mathrm{C}$ in the Gulf of Papua deltaic complex (Papua New Guinea): Net loss of terrestrial C and diagenetic fractionation of $\mathrm{C}$ isotopes, Geochim. Cosmochim. Acta, 68, 1815-1825.

Anderson, D. M. (2001), Attenuation of millennial-scale events by bioturbation in marine sediments, Paleoceanography, 16, 352-357.

Arthur, M. A., W. E. Dean, E. D. Neff, B. J. Hay, J. King, and G. Jones (1994), Varve calibrated records of carbonate and organic carbon accumulation over the last 2000 years in the Black Sea, Global Biogeochem. Cycles, 8(2), 195-218.

Arthur, M. A., W. E. Dean, and K. Laarkamp (1998), Organic carbon accumulation and preservation in surface sediments in Peru margin, Chem. Geol., 152, 273-286.

Bard, E. (2001), Paleoceanographic implications of the difference in deep-sea sediment mixing between large and fine particles, Paleoceanography, 16, 235-239.

Bard, E., M. Arnold, J. Duprat, J. Moyes, and J.-C. Duplessy (1987), Reconstruction of the last deglaciation: Deconvolved records of $\delta^{18} \mathrm{O}$ profiles, micropaleontological variations and accelerator mass spectrometric ${ }^{14} \mathrm{C}$ dating, Clim. Dyn., 1, 101-112.

Bauer, J. E., E. R. M. Druffel, D. M. Wolgast, and S. Griffin (2001), Sources and cycling of dissolved and particulate organic radiocarbon in the northwest Atlantic continental margin, Global Biogeochem. Cycles, 15, 615-636. 
Berner, R. A. (1982), Burial of organic carbon and pyrite sulfur in the modern ocean: Its geochemical and environmental significance, Am. J. Sci., 282, 451-473.

Biscaye, P. E., and R. F. Anderson (1994), Fluxes of particulate matter on the slope of the southern Middle Atlantic Bight: SEEP-II, Deep Sea Res., Part II, 41, 459-509.

Bremner, J. M. (1983), Biogenic sediments on the south west African (Namibian) continental margin, in Coastal Upwelling, Its Sediment Record; Part B: Sedimentary Records of Ancient Coastal Upwelling, edited by J. Thiede and E. Suess, pp. 73-103, Plenum Press, New York.

Bremner, J. M., and J. P. Willis (1993), Mineralogy and geochemistry of the clay fraction of sediments from the Namibian continental margin and the adjacent hinterland, Mar. Geol., 115, 85-116.

Brüchert, V., B. Currie, K. R. Peard, H. U. Lass, R. Endler, A. Dübecke, E. Julies, T. Leipe, and S. Zitzmann (2006), Biogeochemical and physical control on shelf anoxia and water column hydrogen sulphide in the Benguela Coastal Upwelling System off Namibia, in Past and Present Water Column Anoxia, edited by L. N. Neretin, pp. 161-193, Springer, New York.

Calvert, S. E., R. M. Bustin, and T. F. Pedersen (1992), Lack of enhanced preservation of sedimentary organic matter in the oxygen minimum zone of the Gulf of California, Geology, 20, 757-760.

Carr, M.-E. (2001), Estimation of potential productivity in Eastern Boundary Currents using remote sensing, Deep Sea Res., Part II, 49, 59-80.

Dickens, A. F., Y. Gélinas, C. A. Masiello, S. G. Wakeham, and J. I. Hedges (2004), Reburial of fossil organic carbon in marine sediments, Nature, 427, 336-339.

Eglinton, T. I., B. C. Benitez-Nelson, A. Pearson, A. P. McNichol, J. E. Bauer, and E. R. M. Druffel (1997), Variability in radiocarbon ages of individual organic compounds from marine sediments, Science, 277, 796-799.

Eglinton, T. I., G. Eglinton, L. Dupont, E. R. Sholkovitz, D. Montluçon, and C. M. Reddy (2002), Composition, age, and provenance of organic matter in NW African dust over the Atlantic Ocean, Geochem. Geophys. Geosyst., 3(8), 1050, doi:10.1029/2001GC000269.

Emeis, K.-C., V. Brüchert, B. Currie, R. Endler, T. Ferdelman, A. Kiessling, T. Leipe, K. Noli-Peard, U. Struck, and T. Vogt (2004), Shallow gas in shelf sediments of the Namibian coastal upwelling ecosystem, Cont. Shelf Res., 24, 627-642.

Espitalié, J., J. L. Laporte, M. Madec, F. Marquis, P. Leplat, J. Paulet, and A. Boutefeu (1977), Méthode rapide de caractérisation des roches mères, de leur potentiel pétrolier et de leur degré d'évolution, Rev. Inst. Fr. Pet., 32, 23-42.

Guinasso, N. L., and D. R. Schink (1975), Quantitative estimates of biological mixing rates in abyssal sediments, J. Geophys. Res., 80, 3032-3043.

Hall, I. R., and I. N. McCave (1998), Glacial-interglacial variation in organic carbon burial on the slope of the N. W. European Continental Margin, Prog. Oceanogr., 42, 37-60.

Hopmans, E. C., S. Schouten, R. D. Pancost, M. T. J. van der Meer, and J. S. Sinninghe Damsté (2000), Analysis of intact tetraether lipids in archaeal cell material and sediments by high performance liquid chromatography/atmospheric pressure chemical ionization mass spectrometry, Rapid Comm. Mass Spectrom., 14, 585-589.

Ingalls, A., S. R. Shah, R. L. Hansmann, L. I. Aluwihare, G. M. Santos, E. R. M. Druffel, and A. Pearson (2006), Quantifying archaeal community autotrophy in the mesopleagic ocean using natural radiocarbon, Proc. Natl. Acad. Sci., 103, 6442-6447.
Ingram, B. L., and J. R. Southon (1996), Reservoir ages in eastern Pacific coastal and estuarine waters, Radiocarbon, 38, 573-582.

Inthorn, M., T. Wagner, G. Scheeder, and M. Zabel (2006a), Lateral transport controls distribution, quality, and burial of organic matter along continental slopes in high-productivity areas, Geology, 34, 205-208.

Inthorn, M., V. Mohrholz, and M. Zabel (2006b), Nepheloid layer distribution in the Benguela upwelling area offshore Namibia, Deep Sea Res., Part I, 53, 1423-1438.

Inthorn, M., M. Rutgers van der Loeff, and M. Zabel (2006c), A study of particle exchange at the sediment-water interface in the Benguela upwelling area based on ${ }^{234} \mathrm{Th} /{ }^{238} \mathrm{U}$ disequilibrium, Deep Sea Res., Part I, 53, 1742-1761.

Karner, M. B., E. F. DeLong, and D. M. Karl (2001), Archaeal dominance in the mesopelagic zone of the Pacific Ocean, Nature, 409, 507-510.

Keil, R. G., E. Tsamakis, J. C. Giddings, and J. I. Hedges (1998), Biochemical distributions (amino acids, neutral sugars, and lignin phenols) among size-classes of modern marine sediments from the Washington coast, Geochim. Cosmochim. Acta, 62, 1347-1364.

Keil, R. G., A. F. Dickens, T. Arnarson, B. L. Nunn, and A. H. Devol (2004), What is the oxygen exposure time of laterally transported organic matter along the Washington margin?, Mar. Chem., 92, 157-165.

Lass, H. U., and V. Mohrholz (2005), On the fluctuations and vertical structure of the shelf circulation off Walvis Bay, Namibia, Cont. Shelf Res., 25, 1473-1497.

Liebezeit, G., and M. G. Wiesner (1990), Pyrolysis of recent marine sediments: I. Biopolymers, in Advances in Organic Geochemistry 1989: Part II, Molecular Geochemistry, edited by B. Burand and F. Béhar, pp. 1179-1185, Pergamon, New York.

Mayer, L., L. L. Schick, K. R. Hardy, R. Wagai, and J. McCarthy (2004), Organic matter in small mesopores in sediments and soils, Geochim. Cosmochim. Acta, 68, 3863-3872.

McNichol, A. P., E. A. Osborne, A. R. Gagnon, B. Fry, and G. A. Jones (1994), TIC, TOC, DIC, DOC, PIC, POCUnique aspects in the preparation of oceanographic samples for ${ }^{14} \mathrm{C}-\mathrm{AMS}$, Nucl. Instrum. Methods Phys. Res., Sect. B, $92,162-165$.

Mollenhauer, G., and T. I. Eglinton (2007), Diagenetic and sedimentological controls on the composition of organic matter preserved in California Borderland Basin sediments, Limnol. Oceanogr., 52(2), 558-576.

Mollenhauer, G., R. R. Schneider, P. J. Müller, V. Spieß, and G. Wefer (2002), Glacial/interglacial variability in the Benguela upwelling system: Spatial distribution and budgets of organic carbon accumulation, Global Biogeochem. Cycles, 16(4), 1134, doi:10.1029/2001GB001488.

Mollenhauer, G., T. I. Eglinton, N. Ohkouchi, R. R. Schneider, P. J. Müller, P. M. Grootes, and J. Rullkötter (2003), Asynchronous alkenone and foraminifera records from the Benguela Upwelling System, Geochim. Cosmochim. Acta, 67, 2157-2171.

Mollenhauer, G., D. Montluçon, and T. I. Eglinton (2005), Radiocarbon dating of alkenones from marine sediments: II. Assessment of carbon process blanks, Radiocarbon, 47, 413-424.

Monteiro, P. M. S., G. Nelson, A. van der Plas, E. Mabille, G. W. Bailey, and E. Klingelhoeffer (2005), Internal tideshelf topography interactions as a forcing factor governing the large-scale distribution and burial fluxes of particulate organic matter (POM) in the Benguela upwelling system, Cont. Shelf Res., 25, 1864-1876. 
Müller, P. J., G. Kirst, G. Ruhland, I. von Storch, and A. RosellMelé (1998), Calibration of the alkenone paleotemperature index $\mathrm{U}_{37}^{\mathrm{K}^{\prime}}$ based on core tops from the eastern South Atlantic and the global ocean, Geochim. Cosmochim. Acta, 62, 17571772 .

Ohkouchi, N., L. Xu, C. M. Reddy, D. Montluçon, and T. I. Eglinton (2005a), Radiocarbon dating of alkenones from marine sediments: I. Isolation protocol, Radiocarbon, 47, 401-412.

Ohkouchi, N., T. I. Eglinton, K. Hughen, E. Roosen, and L. D. Keigwin (2005b), Radiocarbon dating of alkenones from marine sediments: III. Influence of solvent extraction procedures on ${ }^{14} \mathrm{C}$ measurements of foraminifera, Radiocarbon, 47, 425-432.

Pearson, A., A. McNichol, R. J. Schneider, K. F. von Reden, and Y. Zheng (1998), Microscale AMS ${ }^{14} \mathrm{C}$ measurement at NOSAMS, Radiocarbon, 40, 61-75.

Pearson, A., A. P. McNichol, B. C. Benitez-Nelson, J. M. Hayes, and T. I. Eglinton (2001), Origins of lipid biomarkers in Santa Monica Basin surface sediment: A case study using compound-specific $\Delta^{14} \mathrm{C}$ analysis, Geochim. Cosmochim. Acta, 65, 3123-3137.

Prahl, F. G., L. A. Muehlhausen, and D. L. Zahnle (1988), Further evaluation of long-chain alkenones as indicators of paleoceanographic conditions, Geochim. Cosmochim. Acta, $52,2303-2310$.

Reimers, C. E., R. A. Jahnke, and D. C. McCorkle (1992), Carbon fluxes and burial rates over the continental slope and rise off central California with implications for the global carbon cycle, Global Biogeochem. Cycles, 6, 199-224.

Schouten, S., E. C. Hopmans, E. Schefuß, and J. S. Sinninghe Damsté (2002), Distributional variations in marine crenarchaeotal membrane lipids: A new tool for reconstructing ancient sea water temperatures?, Earth Planet. Sci. Lett., 204, 265-274.

Sinninghe Damsté, J. S., W. I. C. Rijpstra, and G.-J. Reichart (2002), The influence of oxic degradation on the sedimentary biomarker record II. Evidence from Arabian Sea sediments, Geochim. Cosmochim. Acta, 66, 2737-2754.
Smittenberg, R. H., E. C. Hopmans, S. Schouten, and J. Sinninghe Damsté (2002), Rapid isolation of biomarkers for compound specific radiocarbon dating using high-performance liquid chromatography and flow injection analysis-atmospheric pressure chemical ionization mass spectrometry, J. Chromatogr. A, 978, 129-140.

Smittenberg, R. H., E. C. Hopmans, S. Schouten, J. M. Hayes, T. I. Eglinton, and J. S. Sinninghe Damsté (2004), Compoundspecific radiocarbon dating of the varved Holocene sedimentary record of Saanich Inlet, Canada, Paleoceanography, 19, PA2012, doi:10.1029/2003PA000927.

Struck, U., A. V. Altenbach, K.-C. Emeis, J. Alheit, C. Eichner, and R. Schneider (2002), Changes of the upwelling rates of nitrate preserved in the $\delta^{15} \mathrm{~N}$-signature of sediments and fish scales from the diatomaceous mud belt of Namibia, Geobios, $35,3-11$.

Stuiver, M., and H. A. Polach (1977), Discussion: Reporting of ${ }^{14} \mathrm{C}$ data, Radiocarbon, 19, 355-363.

Thomson, J., G. T. Cook, R. F. Anderson, A. B. MacKenzie, D. D. Harkness, and I. N. McCave (1995), Radiocarbon age offsets in different-sized carbonate components of deep-sea sediments, Radiocarbon, 37, 91-101.

Thomson, J., L. Brown, S. Nixon, G. T. Cook, and A. B. MacKenzie (2000), Bioturbation and Holocene sediment accumulation fluxes in the north-east Atlantic Ocean (Benthic Boundary Layer experiment sites), Mar. Geol., 169, 21-39.

Tissot, B. P., and D. H. Welte (1984), Petroleum Formation and Occurrence, Springer, New York.

Trauth, M. H., M. Sarnthein, and M. Arnold (1997), Bioturbational mixing depth and carbon flux at the seafloor, Paleoceanography, 12, 517-526.

Wollast, R. (1998), Evaluation and comparison of the global carbon cycle in the coastal zone and in the open ocean, in The Sea, edited by K. H. Brink and A. R. Robinson, pp. 213-252, John Wiley, Hoboken, N. J.

Wuchter, C., S. Schouten, S. G. Wakeham, and J. S. Sinninghe Damsté (2005), Temporal and spatial variation in tetraether membrane lipids of marine Crenarchaeota in particulate organic matter: Implications for $\mathrm{TEX}_{86}$ paleothermometry, Paleoceanography, 20, PA3013, doi:10.1029/2004PA001110. 